\title{
A Review of Control-Oriented Bioelectrochemical Mathematical Models of Microbial Fuel Cells
}

\author{
Dipankar Deb ${ }^{1, *, \dagger}$, Ravi Patel ${ }^{2,+}$ (ID) and Valentina E. Balas ${ }^{3}$ \\ 1 Department of Electrical Engineering, Institute of Infrastructure Technology Research and Management, \\ Ahmedabad 380026, India \\ 2 Department of Electrical, Computer and Software Engineering, The University of Auckland, Auckland 1142, \\ New Zealand; ravi13.ele@gmail.com \\ 3 Department of Automatics and Applied Software, Faculty of Engineering, University "Aurel Vlaicu" Arad, \\ 310032 Arad, Romania; balas@drbalas.ro \\ * Correspondence: dipankardeb@iitram.ac.in \\ + These authors contributed equally to this work.
}

Received: 6 April 2020; Accepted: 11 May 2020; Published: 14 May 2020

check for updates

\begin{abstract}
A microbial fuel cell (MFC) is a potentially viable renewable energy option which promises effective and commercial harvesting of electrical power by bacterial movement and at the same time also treats wastewater. Microbial fuel cells are complicated devices and therefore research in this field needs interdisciplinary knowledge and involves diverse areas such as biological, chemical, electrical, etc. In recent decades, rapid strides have taken place in fuel cell research and this technology has become more efficient. For effective usage, such devices need advanced control techniques for maintaining a balance between substrate supply, mass, charge, and external load. Most of the research work in this area focuses on experimental work and have been described from the design perspective. Recently, the development in mathematical modeling of such cells has taken place which has provided a few mathematical models. Mathematical modeling provides a better understanding of the operations and the dynamics of MFCs, which will help to develop control and optimization strategies. Control-oriented bio-electrochemical models with mass and charge balance of MFCs facilitate the development of advanced nonlinear controllers. This work reviews the different mathematical models of such cells available in the literature and then presents suitable parametrization to develop control-oriented bio-electrochemical models of three different types of cells with their uncertain parameters.
\end{abstract}

Keywords: microbial fuel cells; anode-cathode compartment; anode compartment; uncertain parameters; control-oriented models; mathematical modeling

\section{Introduction}

Electricity demands have seen a rapid increase due to industrial growth and rise in population. Fossil fuels (coal, natural gases), nuclear, and renewable sources are the avenues for providing this need $[1,2]$. Electricity generated from fossil fuels negatively impacts the environment by polluting the atmosphere and resulting in global warming. Continued innovation in renewable energy sources can over time result in a drop in fossil fuel-based energy dependence [3]. Of late, a significant proportion of electricity is generated from renewable energy sources like wind, geothermal, solar, biomass $[4,5]$ fuel cell, etc. as a result of a lot of research work carried out in this sector. The power generated from such sources is clean (do not produce pollutant gases) and are more efficient [6]. A hydrogen-based fuel cell is also a promising renewable energy source which transforms chemical energy into electrical energy. However, conventional hydrogen-based fuel cells have some disadvantages like high production cost and mass generation, hydrogen storage, and transportation [7]. 
Wastewater containing fermentative, anodophilic, and methanogenic bacterias are drastically growing because of industrial growth and accelerated human population, thereby necessitating efficient wastewater treatment solutions. However, most of such technologies are inefficient, expensive, and not sustainable [8]. Microbial fuel cells (MFCs) provide a new technology that can act as pollutant removal devices by using microorganisms available in wastewater as catalysts to oxidize substrates and produce much needed electric power. MFC technologies have unique features and abilities to solve energy and environmental issues in remote, rural, and dry areas. MFCs are used as power supplies for underwater monitoring devices, remote biosensors, biological oxygen demand monitoring, and bio-hydrogen production along with wastewater treatment applications. The major advantages of MFCs include low operational temperature, less excess activated sludge, higher conversion efficiency, no requirement of gas treatment, direct electrical energy conversion from the substrate, and easy implementation in areas with limited electrical facilities [9-11].

In the anode chamber, a mixture of microorganisms culture and suitable substrates are placed, which generates protons and electrons by the oxidation process. Substrates are chosen based on types of microorganisms culture and performance requirements [12]. Microorganisms have an inherent capacity to transport developed electrons on the anode surface in two ways: direct or indirect electron transfer. In the direct transfer process, electrons are transported via nanowires or intracellular mediator, whereas additional external mediator is used in an indirect way [13]. Most of the MFC setups have two electrodes, namely anode and cathode, nourishment for bacterias (substrates), membranes, and microorganisms culture. The fundamental organization of the different sections in an MFC is shown in Figure 1.

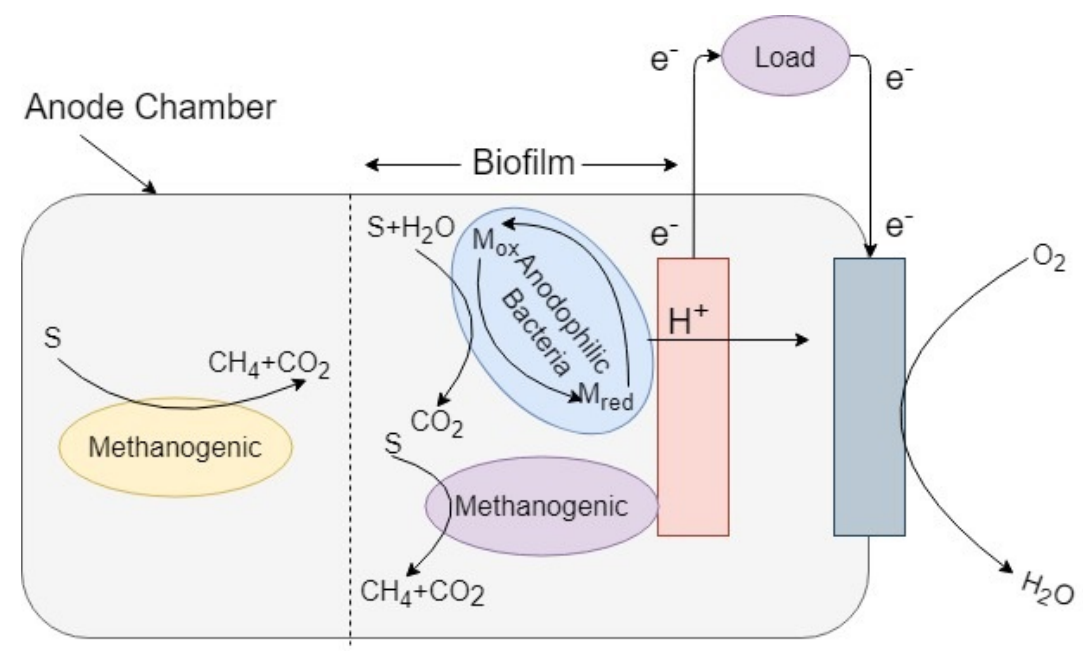

Figure 1. Single Chamber two-population Microbial Fuel Cell without PEM.

Now, electrons at the anode surface are transported to the cathode via an external electrical load [14], and the protons are transported to the cathode through cation exchange membrane (CEM). Finally, generated electricity is captured across the electrical load between electrodes and also filtered water is produced at cathode by a combination of electrons and protons that came from the anode compartment.

MFC setups are mainly classified by three major aspects such as design, operation, and biological aspects. Each aspect has some subdivisions to understand the functionality and detailed behavior of MFC. Several review articles have focused on performance improvement, electrode and membrane material advancement, electron transfer mechanism, and design and parameter effects [15-25]. Recent advancement in bacterio-algal MFCs with operational parameter and their effect on power density and its efficiency have been investigated [26]. Another recent review work has briefly overviewed MFC technology for wastewater treatment, the possible future applications, and primary challenges [27]. However, for the most part, these comprehensive reviews have mostly focused 
on the development undertaken on MFCs, their challenges, and future applications. MFCs are a challenging technology still confined to the laboratory level and awaiting significant commercialization. Model-based design and control approaches would be helpful for the commercialization of MFCs technologies under different operating conditions. The mathematical models relate between various parameters, system inputs and outputs, and also system characteristics. Few bio-electrochemical MFC models are formulated and validated with certain assumptions and circumstances. There are some review articles available that have focused on the mathematical modeling of MFCs [28-32]. However, these reviews do not delve into control-oriented models which parametrize the uncertain parameters of MFCs.

This work provides a review of the different MFCs and control-oriented models of such MFCs. In this work, a literature review of mathematical modeling of different MFCs is provided along with their controllable models with identified uncertain parameters. It is the first attempt to present an extensive description of the three models of MFCs such as single species anode based MFC, two species anode based MFC, and single species anode-cathode based MFC with uncertain parameters. The paper is organized as follows: Modeling strategies and description of mathematical models of MFCs are summarized in Section 2. The control-oriented models with their uncertain parameters are summarized in Section 3. Modeling of MFCs based on its applications is summarized in Section 4. Developments in control strategies of MFCs are summarized in Section 5. Section 6 presents the perspectives and challenges of MFCs, followed by the concluding section.

\section{Modeling Strategies and Description of Mathematical Models}

Mathematical model of any system transforms the compound system operations into facile mathematics representing dynamical equations. A mathematical model of the MFC system incorporates the impact of parameters such as design (i.e., membrane and electrode materials, type and volume of chambers, etc.), operational (i.e., number of populations and source of microorganisms, electron transfer mechanisms, etc.), and biological parameters (temperature, $\mathrm{pH}$, resistances, flow rate, etc.) on the system output $[33,34]$. There are several ways to develop a mathematical model of MFC by considering different factors. For instance, based on the culture of the microorganism accounted for in the model development, either it can be a pure culture with one or two microorganisms or mixed culture with multiple types of microorganisms or based on the way of transportation of extracellular electron considered in the model, either it can be direct transfer or indirect transfer, or whether biofilm is considered or not $[35,36]$. Apart from these factors, mathematical modeling of the MFCs is done in either engineering or statistical approaches as shown in Figure 2.

Furthermore, engineering-based models can be done in two ways, either ordinary differential equations (ODE) or partial differential equations (PDE). ODE based models are accounting for only time dependence and no spatial dimension. ODE models have simple formulation and computation that is quite faster at a relatively low computational cost. PDE based models are accounting for both time and spatial dimensions, which makes a more informative and comprehensive system. However, the computational time and cost both are quite higher than the ODE models. One can choose as per the requirements based on performance and applications.

Table 1 provides a brief overview of the important factors accounted for in some of the familiar MFC models. Zhang and Halme proposed one of the first simplest mathematical models of dual-chamber MFC, which is based on ODE. In this model, Monod kinetics are used to represent the substrate consumption by the microorganisms and redox reactions. Nernst's equation and Faraday's law are used for formulating the dynamics of emf and electrochemical current, respectively. The proposed model is proposed by taking several assumptions but provides the best initiative model for MFC study and used as a benchmark for the advanced models. This model is validated through simulation and experimental setups with different electrical load conditions [37]. 




Figure 2. Mathematical modeling approaches.

Table 1. Modeling categorization of Microbial Fuel Cells.

\begin{tabular}{|c|c|c|c|c|c|c|}
\hline $\begin{array}{l}\text { Model } \\
\text { Approach }\end{array}$ & $\begin{array}{l}\text { Compartment } \\
\text { Modeled }\end{array}$ & Mediator & $\begin{array}{l}\text { No. of } \\
\text { Bacteria }\end{array}$ & $\begin{array}{l}\text { Reaction } \\
\text { Equations }\end{array}$ & $\begin{array}{l}\text { Time and Space } \\
\text { Resolution }\end{array}$ & Ref. \\
\hline \multirow{4}{*}{ ODE } & \multirow[b]{2}{*}{ Anode } & $\begin{array}{l}\text { Yes } \\
\text { (External) } \\
-\end{array}$ & $\begin{array}{l}\text { One } \\
\text { One }\end{array}$ & $\begin{array}{l}\text { Monod,Tafel, } \\
\text { Nernst. } \\
\text { Monod, } \\
\text { Nernst. }\end{array}$ & $\begin{array}{l}\text { 1D, } \\
\text { Dynamic. } \\
\text { 1D, } \\
\text { Dynamic. }\end{array}$ & $\begin{array}{l}{[37]} \\
{[38]}\end{array}$ \\
\hline & & $\begin{array}{l}\text { Yes } \\
\text { (Intracellular) }\end{array}$ & Two & $\begin{array}{l}\text { Nernst, } \\
\text { Double Monod, } \\
\text { Butler-Volmer. }\end{array}$ & $\begin{array}{l}\text { 1D, } \\
\text { Steady St., } \\
\text { Dynamic. } \\
\text { 1D, } \\
\text { Dynamic. }\end{array}$ & [39] \\
\hline & \multirow[t]{2}{*}{$\begin{array}{l}\text { Anode, } \\
\text { Cathode. }\end{array}$} & $\begin{array}{l}\text { No } \\
\text { No } \\
\text { Yes } \\
\text { (External) }\end{array}$ & One & $\begin{array}{l}\text { Monod, } \\
\text { Butler-Volmer. } \\
\text { Monod, } \\
\text { Tafel. } \\
\text { Monod,Tessier, } \\
\text { Blackman, } \\
\text { Nernst. }\end{array}$ & $\begin{array}{l}\text { 1D, } \\
\text { Steady St., } \\
\text { Dynamic. }\end{array}$ & $\begin{array}{l}41] \\
{[42]} \\
{[43]}\end{array}$ \\
\hline & & No & Two & - & $\begin{array}{l}\text { 1D, } \\
\text { Steady St.. }\end{array}$ & [44] \\
\hline \multirow[t]{2}{*}{ PDE } & Anode & \multirow[t]{2}{*}{ No } & \multirow[t]{2}{*}{ One } & Monod, Nernst. & $\begin{array}{l}\text { 1D, } \\
\text { Steady St., } \\
\text { Dynamic. } \\
\text { 2D, } \\
\text { Steady St.. }\end{array}$ & [45] \\
\hline & $\begin{array}{l}\text { Anode, } \\
\text { Cathode. }\end{array}$ & & & $\begin{array}{l}\text { Butler-Volmer } \\
\text { Monod,Nernst. }\end{array}$ & $\begin{array}{l}\text { 1D, } \\
\text { Steady St.. }\end{array}$ & [47] \\
\hline $\begin{array}{l}\text { PDE\& } \\
\text { ODE }\end{array}$ & $\begin{array}{l}\text { Cathode, } \\
\text { Anode. } \\
\text { Anode }\end{array}$ & $\begin{array}{l}\text { Yes } \\
\text { (External) }\end{array}$ & $\begin{array}{l}\text { One } \\
\text { Multiple }\end{array}$ & $\begin{array}{l}\text { Monod,Nernst. } \\
\text { Double Monod, } \\
\text { Butler-Volmer, } \\
\text { Nernst. }\end{array}$ & $\begin{array}{l}\text { Steady St.. } \\
\text { 1D,2D,3D. } \\
\text { 3D, } \\
\text { Steady St.. }\end{array}$ & $\begin{array}{l}{[48]} \\
{[49]}\end{array}$ \\
\hline
\end{tabular}


Picioreanu et al. proposed a dual-chamber MFC model with batch mode configuration. In this model, acetate is used as a substrate and Geobacter sulfurreducens as a microorganism culture. It is quite a simple mathematical model based on ODE. It represents the accurate dynamics of anode chamber with suspended cells and electron transportation through a diffusible mediator. The dynamics of current density are presented using the Butler-Volmer equation and also the effect of different resistances including internal and external resistances is studied to analyze the output of MFC [48]. This model is more comprehensive compared to Zhang and Halme's model, but they have considered only one simple substrate (acetate) for experimental purposes.

Zeng et al. proposed an MFC model that accounted for the phenomena in an anode and cathode chamber with a pure culture of microorganism. The proposed model is an approximately similar model of a conventional chemical fuel cell. The Butler-Volmer equation is used to represent the electrochemical reaction happening at anode and cathode chamber. In addition, Monod kinetics equation is used to represent the mass balances during MFC operation. In this model, positive ions are not considered in the cathode reaction. The total MFC voltage is determined after considering the voltage losses due to over-potentials and resistances. The model is validated using two distinct substrate feed such as acetate and glucose-glutamic acid. Glucose-glutamic acid is used as a solution to make artificial wastewater. The only limitation of this model is that it does not account for the biofilm phenomena at the anode that has appeared to remarkably affect the overall performance of MFC. However, this model is very simple for performing experiments and also assisting as a good benchmark for the development of dual-chamber MFC models [41].

Pinto et al. have developed an ODE based dynamic model of single-chamber MFC. It only illustrates the dynamics of the anodic chamber considering two microorganisms' populations (anodophilic and methanogenic bacteria). Monod kinetics are used to represent the dynamics of mass balances of the substrate, both microorganisms' concentrations and intracellular mediator. Nernst's equation is used to represent the electrochemical dynamics. The electrodes' potentials and electrochemical current are calculated using Ohm's law. The parameters of the model are estimated by applying the Neder-Mead simplex algorithm. This model is comparatively easy to implement and enables fast numerical computation [39]. Shankar et al. proposed mathematical modeling of continuous mode, dual-chamber MFC. In this model, glucose glutamic acid is used as a substrate and the study is carried out to analyze the effect of temperature variations on the current density in both the chambers and also heat transfer through the membrane [44].

Oliveira et al. proposed an extensive dual-chamber MFC model by incorporating heat balance and biofilm formation. A combination of Monod kinetics and Tafel's equation is used to model the anode chamber's dynamics. However, only Tafel's equation is used to model the cathode chamber's dynamics. Fick model is utilized to illustrate the mass transfer mechanisms in the electrodes and biofilm, and also Fourier's law is used to describe heat balance. The simulation and experimental studies on this model indicate the impact of current density on the over-potentials, biofilm, and profiles of different concentrations and temperature. This model is considered as an extended version of Zeng's model [42]. This study doesn't include dynamic analysis of this model. Thus, it can be challenging to find the influence of operational parameters on MFCs overall performances. Recio-Garrido et al. proposed a combined bioelectrochemical-electrical MFC model with a single microorganism culture. This model enables process optimization as well as real-time estimation of physical and electrical parameters [40].

Esfandyari et al. developed a mathematical model for batch mode as well as continuous mode dual-chamber MFC with a pure culture of Shewanella [43,50]. In this study, three different kinetics models such as Monod kinetics, Blackman model, and Tessier model are investigated to calculate the microorganisms growth rate. Activation, ohmic and concentration losses are accounted for to calculate the final MFC output voltage. This study shows that the Monod kinetics model is far better and more accurate than the other two kinetic models. The process of MFC modeling and optimization 
of parameters can be found in [51,52] The major limitation of this model is uniformly distributed quantities, which is considered one of the influencing factors of biofilm's dynamic performance.

\section{Control-Oriented Mathematical Models}

MFCs performances are significantly dependent on the design, operational, and biological parameters, which are briefly discussed in Section 2. Therefore, MFC operation should be carried out under a controlled environment to get a steady output with the best possible efficiency. Thus, advanced control strategies are required for the controlled operation of MFCs. Consequently, a control-oriented mathematical model is needed to develop advanced control strategies. In this section, control-oriented mathematical models of three different MFCs with their uncertain parameters are proposed, which can be useful for developing advanced control strategies.

\subsection{Single Chamber MFC Model with a Single Microorganism}

Abul et al. proposed a single-chamber MFC model with pure microorganism culture. The principal operation of MFC can be illuminated by Figure 3. It illustrates the chemical reaction process and also shows the types of substrate and microorganism used in the modeling process. In this model, some reasonable assumption has been taken [38].

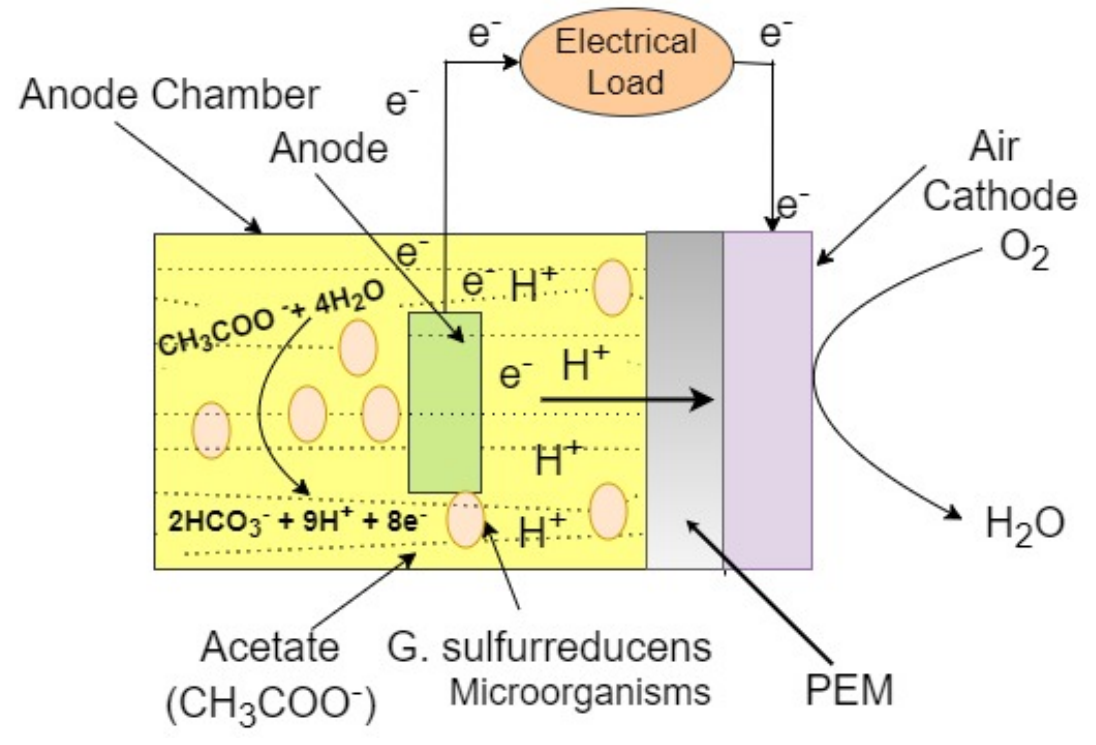

Figure 3. Single chamber MFC with PEM [38].

The overall chemical reaction during the operation of MFC is given by

$$
\begin{aligned}
\mathrm{CH}_{3} \mathrm{COO}^{-}+4 \mathrm{H}_{2} \mathrm{O} & \rightarrow 2 \mathrm{HCO}_{3}^{-}+9 \mathrm{H}^{+}+8 e^{-}, \\
\mathrm{O}_{2}+4 \mathrm{H}^{+}+4 e^{-} & \rightarrow 2 \mathrm{H}_{2} \mathrm{O} .
\end{aligned}
$$

where $\mathrm{CH}_{3} \mathrm{COO}^{-}$is the substrate. $\mathrm{HCO}_{3}^{-}$is the byproduct of this operation. In this modeling process, Monod kinetics are used to represent the growth rate of microorganisms, which is given in Table 2.

The substrate utilization rate and microorganisms growth rate are associated with microorganism yield, $Y$ as

$$
\mu_{\max }=\Upsilon q_{\max } .
$$

where $q_{\max }$ is the maximum value of substrate utilization rate. The comprehensive modeling of single-chamber MFC with a single microorganism is presented in [38]. 
Table 2. Equations in physical and bio-electrochemical models of Microbial Fuel Cells [28].

\begin{tabular}{|c|c|c|}
\hline No. & Equation & Description \\
\hline 1. & $\begin{array}{l}\text { Monod Kinetics } \\
\mu=\mu_{\max } \frac{C_{s}}{K_{s}+C_{s}}\end{array}$ & $\begin{array}{l}\text { It illustrates microorganisms grwoth and substrate utilization rate. } \\
\mu=\text { specific growth rate, } \mu_{\max }=\text { maximum value of } \mu, C_{s}=\text { substrate } \\
\text { concentration, } K_{s}=\text { Monod constant. }\end{array}$ \\
\hline 2. & $\begin{array}{l}\text { Tafel } \\
E=E_{e q}+\frac{R T}{(1-\alpha) n F} \ln \left(\frac{i}{i_{0}}\right)\end{array}$ & $\begin{array}{l}\text { It describes electrodes electrochemical current density and potentials. } \\
E=\text { electrode potential, } E_{e q}=\text { equilibrium potential, } i=\text { current density, } \\
i_{0}=\text { exhcnage current density, } F=\text { Farady's constant, } R=\text { ideal gas } \\
\text { constant, } T=\text { temperature, } \alpha=\text { charge transfer coefficient. }\end{array}$ \\
\hline 3. & $\begin{array}{l}\text { Nernst } \\
E=E_{0}-\frac{R T}{(1-\alpha) n F} \ln (Q)\end{array}$ & $\begin{array}{l}\text { It describes electrode potential based on an electrochemical reaction. } \\
E_{0}=\text { standard electrode potential, } n=\text { number of electrons, } \\
Q=\text { reaction quotient. }\end{array}$ \\
\hline 4. & $\begin{array}{l}\text { Butler-Volmer } \\
i=i_{0}\left[\exp \left(\alpha_{a} \frac{n F}{R T}\left(E-E_{e q}\right)\right)\right. \\
\left.-\exp \left(-\alpha_{c} \frac{n F}{R T}\left(E-E_{e q}\right)\right)\right]\end{array}$ & $\begin{array}{l}\text { It illustrate electrochemical kinetics of anode and cathode reactions. } \\
\alpha_{a}, \alpha_{c}=\text { charge transfer coefficients of anode and cathode. }\end{array}$ \\
\hline
\end{tabular}

The control-oriented mathematical modeling of single-chamber MFC with a pure culture of microorganism is given by

$$
\begin{aligned}
\dot{x_{1}} & =-\gamma^{-1} \cdot \gamma^{-1} \frac{x_{1}}{K_{s}+x_{1}} x_{2}+u\left(S_{o}-x_{1}\right), \\
\dot{x_{2}} & =\left(\gamma^{-1} \frac{x_{1}}{K_{s}+x_{1}}-K_{d}-u\right) x_{2} .
\end{aligned}
$$

where $x_{1}, x_{2}$, and $u$ are the state variables, and input of the system, respectively. $X_{1}$ and $X_{2}$ stand for substrate and microorganism's biomass concentrations. Dilution rate (ratio of feed flow rate to chamber volume) is considered as the input, $u . S_{0}$ and $K_{d}$ refer to the initial substrate concentration and microorganisms decay constant, respectively. The uncertain parameter is denoted by $\gamma^{-1}$, which is maximum microorganism growth rate, $\mu_{\max }$. It significantly relies on the types of substrate and microorganisms used during the operation of MFC. The typical values and initial conditions of the parameters can be found in [53,54].

\subsection{Single Chamber MFC Model with Two Microorganisms}

Pinto et al. proposed a single-chamber MFC model with two microorganisms namely anodophilic and methanogenic. Several reasonable assumptions have been taken while modeling of MFC. The principal operation of MFC can be illuminated by Figure 1. The chemical reactions happening in the anode chamber are given by

$$
\begin{aligned}
S+M_{o} & \rightarrow M_{r}+\mathrm{CO}_{2}, \\
M_{r} & \rightarrow M_{o}+e^{-}+H^{+}, \\
S & \rightarrow \mathrm{CH}_{4}+\mathrm{CO}_{2},
\end{aligned}
$$

In this model, Monod kinetics is used to represent the growth rate of both the microorganisms. Moreover, the anodophilic microorganism's growth rate significantly relies on the substrate concentration and mediator, whereas the growth rate of methanogenic microorganism is only dependent on the substrate concentration. The comprehensive modeling of single-chamber MFC with two microorganisms is presented in [39].

The control-oriented mathematical model of single chamber MFC with two microorganisms is given by 


$$
\begin{aligned}
\dot{x_{1}} & =-k_{1} \theta_{1}^{*} \frac{x_{1}}{K_{s, a}+x_{1}} \frac{x_{4}}{K_{M}+x_{4}} x_{2}-k_{2} \theta_{2}^{*} \frac{x_{1}}{K_{s, m}+x_{1}} x_{3}+u\left(S_{o}-x_{1}\right), \\
\dot{x_{2}} & =x_{2}\left(\theta_{1}^{*} \frac{x_{1}}{K_{s, a}+x_{1}} \frac{x_{4}}{K_{M}+x_{4}}-K_{d, a}-u \alpha_{a}\right), \\
\dot{x_{3}} & =x_{3}\left(\theta_{2}^{*} \frac{x_{1}}{K_{s, m}+x_{1}}-K_{d, m}-u \alpha_{m}\right) \\
\dot{x_{4}} & =-\theta_{1}^{*} \frac{x_{1}}{K_{s, a}+x_{1}} \frac{x_{4}}{K_{M}+x_{4}}+\gamma \frac{I_{M F C}}{z F} \frac{1}{V x_{2}} .
\end{aligned}
$$

where $x_{i}, i=1,2 \ldots 4$ are the state variables, namely substrate concentration, anodophilic microorganism concentration, methanogenic microorganism concentration, and oxidized mediator fraction, respectively. $u$ is the input, which is the dilution rate. Subscripts ' $a$ ' and ' $m$ ' refer to the anodophilic and methanogenic microorganisms. $K_{M}$ and $V$ are the mediator constant and chamber volume, respectively. MFC current is denoted by $I_{M F C} . k_{1}$ and $k_{2}$ are the inverse of the microorganisms yields. Other parameters' names can be found in Table 2 . The uncertain parameters, $\theta_{1}^{*}$ and $\theta_{2}^{*}$ refer to the maximum growth rate of anodophilic and methanogenic microorganisms, respectively. The typical values of parameters and bounds of uncertain parameters can be found in [53].

\subsection{Dual Chamber MFC Model with Single Microorganism}

Zeng et al. proposed a dual-chamber MFC model with a pure culture of microorganism [41]. The principal operation of dual-chambered MFC can be illuminated by Figure 4.

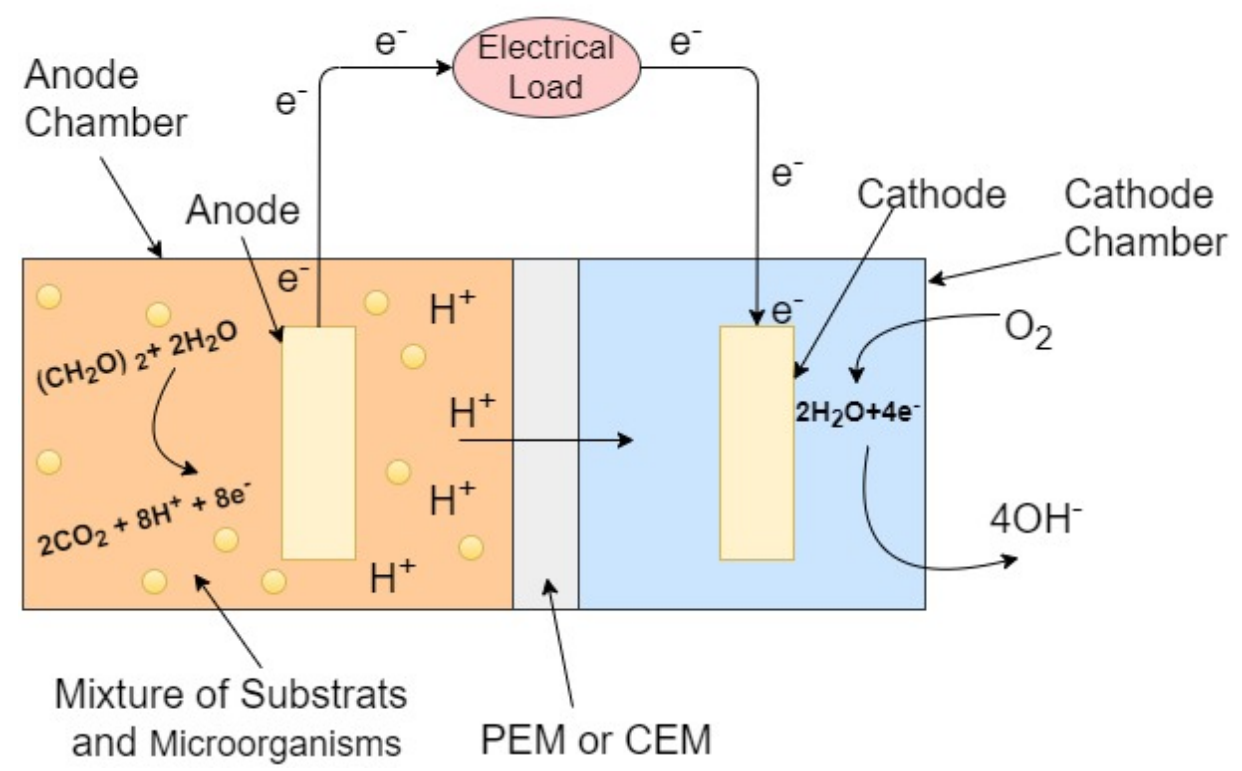

Figure 4. Dual Chamber MFC with Pure Culture Microorganism [41].

The overall chemical reactions in both anode and cathode chambers are given by

$$
\begin{aligned}
& \left(\mathrm{CH}_{2} \mathrm{O}\right)_{2}+2 \mathrm{H}_{2} \mathrm{O} \rightarrow 2 \mathrm{CO}_{2}+8 \mathrm{H}^{+}+8 e^{-}, \\
& \mathrm{O}_{2}+4 e^{-}+2 \mathrm{H}_{2} \mathrm{O} \rightarrow 4 \mathrm{OH}^{-} .
\end{aligned}
$$

The control-oriented dynamics of anode chamber operation are given by 


$$
\begin{aligned}
& \dot{x_{1}}=-\frac{A_{m}}{V_{a}} K_{1}^{0} \exp \left(\delta_{1}^{*}\left(\beta_{1} x_{1}-x_{5}\right)\right) \frac{x_{1}}{K_{A C}+x_{1}}\left(x_{4}-Y x_{1}\right)+u_{1}\left(S^{i n}-x_{1}\right), \\
& \dot{x_{2}}=u_{1}\left(S^{i n}+\frac{1}{2} C_{C O_{2}}^{i n}-x_{2}\right) \\
& \dot{x_{3}}=u_{1}\left(S^{i n}+\frac{1}{8} C_{H}^{i n}-x_{3}\right) \\
& \dot{x_{4}}=Y u_{1}\left(S^{i n}-x_{1}\right)+\frac{u_{1}}{f_{x}}\left(X^{i n}-x_{4}+Y x_{1}\right)-K_{d}\left(x_{4}-Y x_{1}\right), \\
& \dot{x_{5}}=\beta_{1} u_{1}\left(S^{i n}-x_{1}\right)-\frac{3600 i_{\text {cell }}}{C_{\text {cap }, a}}
\end{aligned}
$$

where $x_{i}, i=1,2, \ldots, 5$ are state variables. $x_{1}$ is the substrate concentration, $S$. Other state variables are defined by

$$
\begin{aligned}
& x_{2}=S+\frac{1}{2} C_{\mathrm{CO}_{2}}, \quad x_{3}=S+\frac{1}{8} C_{H}, \\
& x_{4}=Y S+X, \quad x_{5}=\beta_{1} S-\eta_{a},
\end{aligned}
$$

$\mathrm{C}_{\mathrm{CO}_{2}}, \mathrm{C}_{\mathrm{H}}$, and $\mathrm{X}$ are the concentration of carbon dioxide, hydrogen, and biomass, respectively. Superscript ' $i n^{\prime}$ refers to influent. The dilution rate is considered as system input $u$. Other parameters can be found in [53]. The uncertain parameter is defined by $\delta_{1}^{*}=\frac{\beta F}{R T}$. It significantly relies on the operational temperature.

The control-oriented dynamics of cathode chamber operation are given by

$$
\begin{aligned}
\dot{x_{6}} & =u_{2}\left(C_{O_{2}}^{i n}-x_{6}\right)-\frac{A_{m} K_{2}^{0}}{V_{c}} \exp \left(\delta_{2}^{*}\left(x_{9}-\zeta_{2} x_{6}\right)\right) \frac{x_{6}}{K_{O_{2}}+x_{6}} \\
\dot{x_{7}} & =u_{2}\left(C_{O_{2}}^{i n}-\frac{1}{4} C_{O H}^{i n}-x_{7}\right) \\
\dot{x_{8}} & =u_{2}\left(C_{M}^{i n}-x_{8}\right)+\frac{A_{m} N_{M}}{V_{c}} \\
\dot{x_{9}} & =\beta_{2} u_{2}\left(C_{O_{2}}^{i n}-x_{1}\right)-\frac{3600 i_{\text {cell }}}{C_{c a p, c}}
\end{aligned}
$$

where $x_{i}, i=6,7, \ldots, 9$ are state variables. $x_{6}$ is the oxygen concentration, $C_{\mathrm{O}_{2}}$. Other state variables are defined by

$$
x_{7}=C_{\mathrm{O}_{2}}+\frac{1}{4} C_{\mathrm{OH}}, x_{8}=C_{M}, x_{9}=\beta_{2} C_{\mathrm{O}_{2}}+\eta_{c},
$$

where $\beta_{2}$ is a constant defined as $4 F V_{c} / A_{m}$. Other parameters can be found in [53]. The uncertain parameter is defined by $\delta_{2}^{*}=\frac{(\alpha-1) F}{R T}$. It largely relies on the operational temperature and input feed flow rate. These uncertain parameters can be estimated online through adaptive control mechanisms. The above control-oriented models have considered uncertainties in parameters, although one can also consider another uncertainties (i.e., measured, combined, and expanded uncertainties) while modeling MFCs [55].

MFC Models presented in Sections 3.1 and 3.2 are based on the dynamics of microorganisms growth and decay rates. These models come up with the influence of substrates on the microorganisms' growth rates. Therefore, control engineers can develop controllers to control the microorganisms' growth rate by varying the substrate concentration as per the desired MFC performances. In this modeling process, the effect of internal and external temperature is neglected, although it is an 
important factor for bacterial growth rate (certain bacteria can remain alive within a specific range of temperature). Maximum efficiency of MFCs can be achieved by maintaining appropriate internal and external temperature during the whole operation. Moreover, one can choose the MFC models based on several criteria such as the number of microorganisms' populations (i.e., one or two populations), controllers' simplicity, individual applications, and economical aspects. However, the models discussed in Section 3.3 are based on the dynamics of chemical reactions happening in both chambers of MFCs. The temperature of the operation is considered during the modeling process. The dynamics of this model are similar to conventional hydrogen-based fuel cells. There are several well-known advanced controllers already available for conventional fuel cells. Therefore, it could be easy to develop the same kind of controllers for MFCs.

\section{Modeling of MFCs Based on Applications}

The key aim of MFC operation is to obtain maximum power density just as other energy-providing devices. Models discussed in previous sections are based on the basic principle of operation, which have longer computational time and complex microorganisms operations, and also must require interdisciplinary knowledge for practical applications. Thus, application-based MFC models are developed to overcome the aforementioned hurdles to commercialize MFCs for specific predefined applications. There are three main approaches to develop application based models such as equivalent electrical circuits, based on intelligence and a system identification approach.

\subsection{Equivalent Electrical Circuit Based MFC Models}

In this approach, performance characteristics and dynamical behavior of MFC are described by electrical parameters such as voltage, resistance, current, and capacitance. Thus, the voltage and current of the electrical circuit model are referred to as the biological and electrochemical reactions in MFCs. A simple equivalent electrical circuit of MFC shown in Figure 5 is proposed by [56]. In this model, $R_{1}$ and $R_{2}$ are the internal resistances. $C$ and $R_{\text {load }}$ are the internal capacitance and external load of MFC, respectively.

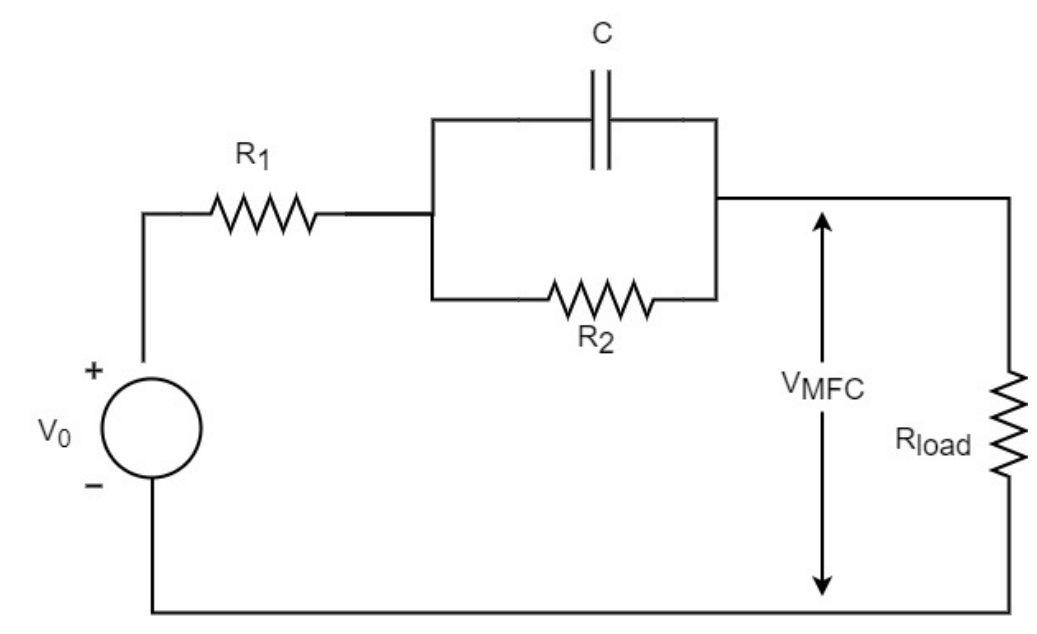

Figure 5. MFC modeling using an Equivalent Electrical Circuit Approach.

Park et al. proposed an advanced version of an equivalent electrical circuit model of MFC by adding parallel capacitance and series resistances. It represents the electron flow in the anode chamber and the charge storage in the MFC system [57]. Research studies in the literature showed that the output power of MFCs is significantly influenced by the internal resistances [58,59]. He and Mansfeld have reported a tool, namely electrochemical impedance spectroscopy, to calculate the internal resistance of MFC and attempted to show the effect of it on MFC's overall performances [60]. The parameters of 
the equivalent electrical circuits such as resistances, capacitance, and phase elements are determined by several approaches (i.e., polarization curve tests) [61-63]. Moreover, the types of electrodes are also one of the key factors to determine the internal resistances [64]. In [65], they have proposed two equivalent electrical models for a two-chamber MFC by using different material of electrodes and studied the effects of electrodes' material. The effect of the biological capacitance of anodes in MFCs has been studied in [66]. Various equivalent electrical models of MFCs have proposed based on the applications in the literature. Furthermore, these models of MFCs may be used to develop advanced control strategies and MPPT algorithms to extract maximum power from MFCs.

\subsection{Intelligence Based MFC Models}

Intelligence-based models did not require in-depth knowledge of MFC and its operation. It requires only a huge number of experimental data to obtain the model through a learning approach. The accuracy of learning models significantly relies on the number of data and its sampling time. MFCs have slow dynamical characteristics, which takes a long time to get the experimental data. The modeling process using learning or intelligence approach is shown in Figure 6.



Figure 6. MFC Modeling using an Intelligence Approach.

Machine learning models like Artificial neural networks (ANN), Support vector machines (SVM), and Extreme learning machines (ELM) are effective in the forecasting of time-series data $[67,68]$, and may be applicable in the operation of multi-variable MFCs after they are constructed. The Relevance Vector Machine (RVM), a Bayesian model for regression of identical functional form to the support vector machine, is proposed by Fang et al. to get MFC's mathematical model for optimizing the output power with multiple variables [69]. Furthermore, ANN is used to analyze the performance characteristics of the MFC model with four manipulated input variables. Moreover, the advanced modeling approach based on ANFIS is acquired to analyze the performance of MFC [70]. Garg et al. have compared the performance of the MFC model obtained from three different approaches such as ANN, MGGP, and SVR, and concluded that the MGGP is far better than the other two approaches, and also stated that ANN is better than the SVM approach [71].

\subsection{System Identification Based MFC Models}

The system identification approach is ideally used when the inputs and outputs of the system are available through experiments. The model identified shows the association between nonlinear characteristics and time function of input and output. The fundamental of modeling process using system identification approach is shown in Figure 7.

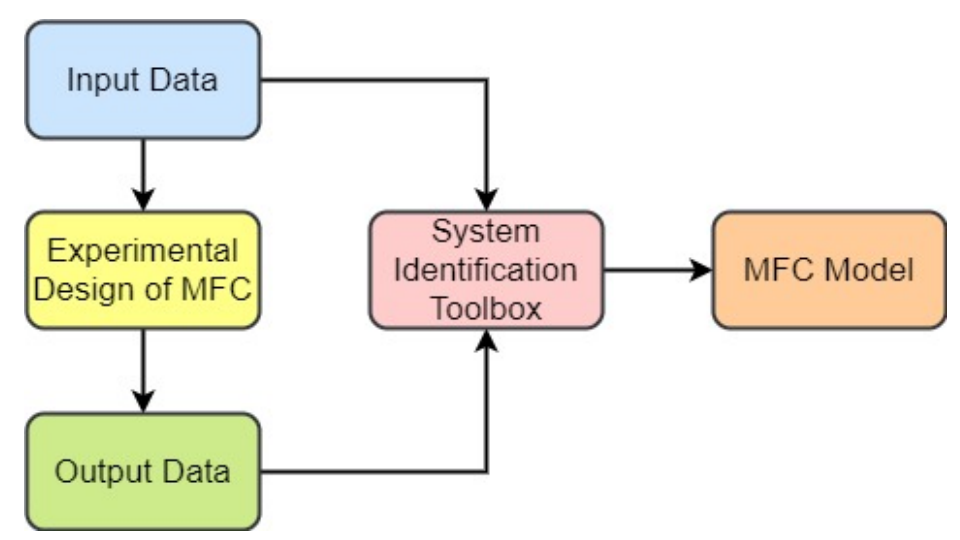

Figure 7. MFC Modeling using a System Identification Approach. 
One can obtain different types of models such as transfer function, state-space, the process model, nonlinear ARX model, and polynomial model. Boghani et al. have proposed an MFC model using a system identification technique. In this model, the electrical load of MFC is considered as a manipulated input variable and voltage of MFC as an output variable [72]. Later, Boghani et al. have developed a gain scheduling controller for the aforementioned MFC model to maintain the output voltage constant [73]. Ravi and Deb have developed dual-chamber MFC transfer function models for both anode and cathode chamber dynamics using a system identification method [74].

\section{Developments in Control Strategies of MFCs}

MFCs have several challenges for controller development such as gains of controllers, nonlinearity in the system, etc.. Selection of manipulated input and output variables can be a critical factor for the development of MFC's controller. The output power of MFC is significantly varied with the change in influent substrate flow rate and initial substrate concentration. Thus, one can choose one of these as a manipulated input variable. It can be chosen based on the type of control strategy and application of MFC [75]. Yan and Fan proposed a fuzzy proportional integral derivative (PID) controller for dual-chamber MFC to maintain a constant output voltage [76]. Later, Fan et al. developed an adaptive fuzzy control for MFC to maintain a constant voltage under various load conditions, and this adaptive controller provides superior steady-state performance and faster response compared to fuzzy control [77]. The model predictive control strategy is applied to dual-chamber MFC by Fan et al. [78]. The robustness of the controller is presented by considering disturbances in operational temperature and substrate concentration and concluded that the proposed controller provides fast response under disturbances.

Patel and Deb proposed a novel adaptive backstepping control strategy for a single chamber MFC with pure culture. In this study, an uncertain parameter (microorganisms growth rate) is estimated online through adaptive control law, and the influent substrate flow rate is considered as a manipulated input variable $[53,54]$. Later, Patel and Deb developed an adaptive control technique for single chamber MFC with two microorganisms. In this control technique, the initial substrate concentration is considered as a manipulated input variable and two uncertain parameters are estimated [79]. An LMI based robust control strategy with norm bounded uncertainty for single chamber MFC is proposed in [80]. In this study, a nonlinear MFC model is linearized at its equilibrium points and dilution rate is considered as a manipulated input variable. An exact linearization of dual-chamber MFC is proposed in [81]. Conventional Model Reference Adaptive Control(MRAC) and MRAC with MIT rule (a rule developed by Massachusetts Institute of Technology for MRAC) strategies for dual-chamber MFC have been proposed in [74]. In this study, the MFC model is obtained from system identification toolbox in MATLAB. Luo et al. proposed an MRAC scheme for MFC to track the output voltage [82].

\section{Perspectives and Challenges}

Recycled wastewater is widely used in dry areas to meet water demand. However, wastewater treatment plants require appropriate water (wastewater with a particular mixture of microorganisms, which can be easily and economically treated) and more energy for treatment. MFCs have potential as renewable energy sources and may be capable of resolving energy and environmental issues. MFCs are more certainly sustainable compared to conventional wastewater treatment technologies. MFC technologies and applications are still at the laboratory level but are great potential industrial wastewater treatment applications and renewable energy sources in remote areas. MFCs have some limiting attributes such as lower power density, materials cost and efficiency. Therefore, more research has been conducted on the electrode, catalyst and membrane materials, types of substrate, transport mechanisms of electrons, etc.. The voltage generated from a single MFC is very low for electrical appliances. Several MFCs can be stacked together to obtain the desired voltage level. Stack MFCs require individual control systems as well as combined control actions for controlled 
voltage and flexible operation. There are certain challenges of mathematical modeling of stack MFCs and physical connections of electrodes. Further improvement should pay a lot of attention to the modeling of stack MFCs and selection of the materials therein.

Apart from these challenges, some researchers have attempted to scale up MFCs as a wastewater treatment plant. In [83], authors have analyzed MFCs performance by treating 200 liters of municipal wastewater. They have combined 96 MFC modules in series-parallel connections and continuously operated for around 300 days. The results of this study concluded that the performance of MFCs is not as good as the laboratory level in terms of energy recovery. Therefore, more intense research on MFCs could help to fill the gap between theoretical and real-world applications to recover more energy from MFCs. The data (i.e., energy consumption and generation, types of wastewater, etc.) of current operating wastewater treatments plants and small scale MFCs are available $[84,85]$.

MFC technologies require significant knowledge of multidisciplinary fields such as microbiology, material science, chemical reactions, and control engineering. The performance of MFCs is enhanced by providing appropriate control and optimization techniques. These techniques help maintain strict reaction conditions such as $\mathrm{pH}$ value, operational temperature, substrate and biomass concentration, and rate of oxygen supply, and also guarantee the maximization of performance. Advanced control schemes such as adaptive control, model predictive control, sliding mode control, etc. are applicable in optimizing the operational parameters of MFCs described in previous sections. Standard mathematical models of MFC are not well documented for all conditions and applications until now. Some attempt has been made to develop models while considering different aspects like biofilm, chemical reactions, activity in microorganisms and substrate oxidization, and electrons transfer. It is necessary to make reasonable modification in the mathematical models for effective control. Control-oriented mathematical models of MFC are necessary to develop suitable advanced control techniques. Certain parameters like growth and consumption rates are sensitive towards and affect the performance of MFCs, and finding appropriate bounds of these parameters are quite challenging and a lot of experimental attention is required. Hence, control-oriented models can contribute to scale-up commercial MFCs with suitable control actions.

\section{Conclusions}

Different mathematical models with appropriate control-oriented forms for Microbial fuel cells are described for an attractive renewable technology which provides electricity and manages wastewater simultaneously. Such devices have found potential applications such as bio-sensors, wastewater treatment plant, underwater monitoring, and remote sensing. Model-based control and optimization techniques developed by identifying and estimating different parameters which vary within practical known bounds are required to evaluate the behavior and performance of such diverse systems under undesirable conditions. Development in different models has been reviewed and analyzed in terms of the microorganisms culture, compartment modeled, modeling perspective, etc.. This paper has reviewed three different control-oriented bio-electrochemical models of MFCs and provides control-oriented mathematical models with uncertain parameters. According to the discussions in previous sections, the following recommendations can be inferred:

- Mathematical model of MFCs, and its control and optimization strategies are chosen based on the specific applications and operational requirements.

- Bounds of uncertain parameters should be practical with a higher confidence level. It is advisable to do more experiments to get accurate practical bounds.

- Several reasonable assumptions may be required in mathematical modeling while developing advanced control and optimization strategies to boost the overall performance of MFCs.

- Selection of appropriate manipulated input variables for successful development of efficient control actions is required. 
- Development of control and optimization strategies for MFCs should be economical, environment friendly, and reliable.

Author Contributions: Writing-original draft, R.P.; Writing second draft and Editing, R.P. and D.D.; Review, D.D., V.E.B., and R.P. All authors have read and agreed to the published version of the manuscript.

Funding: This research received no external funding.

Conflicts of Interest: The authors declare no conflict of interest.

\section{Abbreviations}

The following abbreviations are used in this manuscript:

$\begin{array}{ll}\text { MFC } & \text { Microbial fuel cell } \\ \text { ODE } & \text { Ordinary differential equation } \\ \text { PDE } & \text { Partial differential equation } \\ \text { PID } & \text { Proportional integral derivative } \\ \text { LMI } & \text { Linear matrix inequality } \\ \text { MRAC } & \text { Model reference adaptive control } \\ \text { MIT } & \text { Massachusetts Institute of Technology } \\ \text { PEM } & \text { Proton exchange membrane } \\ \text { CEM } & \text { Cation exchange membrane } \\ \text { ARX } & \text { Auto regressive with external input } \\ \text { MPPT } & \text { Maximum power point tracking } \\ \text { RVM } & \text { Relevance vector machine } \\ \text { ANN } & \text { Artificial neural network } \\ \text { ANFIS } & \text { Adaptive neuro-fuzzy inference system } \\ \text { MGGP } & \text { Multi-gene genetic programming } \\ \text { SVR } & \text { Support vector regression } \\ \text { SVM } & \text { Support vector machine }\end{array}$

\section{References}

1. Logan, B.; Hamelers, B.; Rozendal, R.; Schröder, U.; Keller, J.; Freguia, S.; Aelterman, P.; Verstraete, W.; Rabaey, K. Microbial Fuel Cells: Methodology and Technology†. Environ. Sci. Technol. 2006, 40, 5181-5192. [CrossRef]

2. Akdeniz, F.; Çağlar, A.; Güllü, D. Recent energy investigations on fossil and alternative nonfossil resources in Turkey. Energy Convers. Manag. 2002, 43, 575-589. [CrossRef]

3. Solé, J.; García-Olivares, A.; Turiel, A.; Ballabrera-Poy, J. Renewable transitions and the net energy from oil liquids: A scenarios study. Renew. Energy 2018, 116, 258-271. [CrossRef]

4. Gojiya, A.; Deb, D.; Iyer, K. Feasibility Study Of Power Generation From Agricultural Residue In Comparison With Soil Incorporation Of Residue. Renew. Energy 2018, 134, 416-425. [CrossRef]

5. Deb, D. Intelligent decision-making device for residue incorporation in soil or biomass power plants. J. Intell. Fuzzy Syst. 2020, 1-10. [CrossRef]

6. Choudhury, P.; Uday, U.S.P.; Mahata, N.; Nath Tiwari, O.; Narayan R.; Kanti Bandyopadhyay, T.; Bhunia, B. Performance improvement of microbial fuel cells for waste water treatment along with value addition: A review on past achievements and recent perspectives. Renew. Sustain. Energy Rev. 2017, 9, 372-389. [CrossRef]

7. Peighambardoust, S.J.; Rowshanzamir, S.; Amjadi, M. Review of the Proton Exchange Membranes for Fuel Cell Applications; Elsevier Ltd.: Amsterdam, The Netherlands, 2010.

8. Hu, P.; Ouyang, Y.; Wu, L.; Shen, L.; Luo, Y.; Christie, P. Effects of water management on arsenic and cadmium speciation and accumulation in an upland rice cultivar. J. Environ. Sci. 2015, 27, 225-231. [CrossRef] [PubMed]

9. Mathuriya, A.S.; Sharma, V.N. Bioelectricity production from paper industry waste using a microbial fuel cell by Clostridium species. J. Biochem. Technol. 2009, 1, 49-52.

10. Qin, M.; Hynes, E.A.; Abu-Reesh, I.M.; He, Z. Ammonium removal from synthetic wastewater promoted by current generation and water flux in an osmotic microbial fuel cell. J. Clean. Prod. 2017, 149, 856-862. [CrossRef] 
11. HaoYu, E.; Cheng, S.; Scott, K.; Logan, B. Microbial fuel cell performance with non-Pt cathode catalysts. J. Power Sources 2007, 171, 275-281. [CrossRef]

12. Pant, D.; Van Bogaert, G.; Diels, L.; Vanbroekhoven, K. A review of the substrates used in microbial fuel cells (MFCs) for sustainable energy production. Bioresour. Technol. 2010, 101, 1533-1543. [CrossRef] [PubMed]

13. Lovley, D.R. The microbe electric: Conversion of organic matter to electricity. Curr. Opin Biotechnol. 2008, 19, 564-571. [CrossRef] [PubMed]

14. Lovley, D.R. Bug juice: Harvesting electricity with microorganisms. Nat. Rev. Microbiol. 2006, 4, 497-508. [CrossRef] [PubMed]

15. Venkata Mohan, S.; Velvizhi, G.; Annie Modestra, J.; Srikanth, S. Microbial fuel cell: Critical factors regulating bio-catalyzed electrochemical process and recent advancements. Renew. Sustain. Energy Rev. 2014, 40, 779-797. [CrossRef]

16. ElMekawy, A.; Hegab, H.M.; Losic, D.; Saint, C.P.; Pant, D. Applications of graphene in microbial fuel cells: The gap between promise and reality. Renew. Sustain. Energy Rev. 2017, 72, 1389-1403. [CrossRef]

17. Hindatu, Y.; Annuar, M.S.M.; Gumel, A.M. Mini-review: Anode modification for improved performance of microbial fuel cell. Renew. Sustain. Energy Rev. 2017, 73, 236-248. [CrossRef]

18. Nitisoravut, R.; Regmi, R. Plant microbial fuel cells: A promising biosystems engineering. Renew. Sustain. Energy Rev. 2017, 76, 81-89. [CrossRef]

19. Oh, S.T.; Kim, J.R.; Premier, G.C.; Lee, T.H.; Kim, C.; Sloan, W.T. Sustainable wastewater treatment: How might microbial fuel cells contribute. Biotechnol. Adv. 2010, 28, 871-881. [CrossRef]

20. Kumar, R.; Singh, L.; Zularisam, A. W.; Hai, F. I. Microbial fuel cell is emerging as a versatile technology: A review on its possible applications, challenges and strategies to improve the performances. Int. J. Energy Res. 2017, 42, 369-394. [CrossRef]

21. Xiao, L.; He, Z. Applications and perspectives of phototrophic microorganisms for electricity generation from organic compounds in microbial fuel cells. Renew. Sustain. Energy Rev. 2014, 37, 550-559. [CrossRef]

22. Yang, Y.; Xu, M.; Guo, J.; Sun, G. Bacterial extracellular electron transfer in bioelectrochemical systems. Process Biochem. 2012, 47, 1707-1714. [CrossRef]

23. Schröder, U. Anodic electron transfer mechanisms in microbial fuel cells and their energy efficiency. Phys. Chem. Chem. Phys. 2007, 9, 2619-2629. [CrossRef] [PubMed]

24. Kundu, A.; Sahu, J.N.; Redzwan, G.; Hashim, M.A. An overview of cathode material and catalysts suitable for generating hydrogen in microbial electrolysis cell. Int. J. Hydrogen Energy 2013, 38, 1745-1757. [CrossRef]

25. Santoro, C.; Arbizzani, C.; Erable, B.; Ieropoulos, I. Microbial fuel cells: From fundamentals to applications. A review. J. Power Sources 2017, 356, 225-244. [CrossRef]

26. Saba, B.; Christy, A.D.; Yu, A.; Co, A.C. Sustainable power generation from bacterio-algal microbial fuel cells (MFCs): An overview. Renew. Sustain. Energy Rev. 2017, 73, 75-84. [CrossRef]

27. He, L.; Du, P.; Chen, Y.; Lu, H.; Cheng, X.; Chang, B.; Wang, Z. Advances in microbial fuel cells for wastewater treatment. Renew. Sustain. Energy Rev. 2017, 71, 388-403. [CrossRef]

28. Ortiz-Martínez, V.M.; Salar-García, M.J.; De los Ríos, A.P.; Hernández-Fernández, F.J.; Egea, J.A.; Lozano, L.J. Developments in microbial fuel cell modeling. Chem. Eng. J. 2015, 271, 50-60. [CrossRef]

29. Recio-Garrido, D.; Perrier, M.; Tartakovsky, B. Modeling, optimization and control of bioelectrochemical systems. Chem. Eng. J. 2016, 289, 180-190. [CrossRef]

30. Janicek, A.; Fan, Y.; Liu, H. Design of microbial fuel cells for practical application: A review and analysis of scale-up studies. Biofuels 2014, 5, 79-92. [CrossRef]

31. Luo, S.; Sun, H.; Ping, Q.; Jin, R.; He, Z. A review of modeling bioelectrochemical systems: Engineering and statistical aspects. Energies 2016, 9, 111. [CrossRef]

32. Xia, C.; Zhang, D.; Pedrycz, W.; Zhu, Y.; Guo, Y. Models for Microbial Fuel Cells: A critical review. J. Power Sources 2018, 373, 119-131. [CrossRef]

33. Jadhav, G.S.; Ghangrekar, M.M. Bioresource Technology Performance of microbial fuel cell subjected to variation in $\mathrm{pH}$, temperature, external load and substrate concentration. Bioresour. Technol. 2009, 100, 717-723. [CrossRef] [PubMed]

34. Merkey, B.V.; Chopp, D.L. The Performance of a Microbial Fuel Cell Depends Strongly on Anode Geometry: A Multidimensional Modeling Study. Bull. Math. Biol. 2012, 74, 834-857. [CrossRef] 
35. Picioreanu, C.; Katuri, K.p.; Head, I.M.; Van Loosdrecht, M.C.M.; Scott, K. Mathematical model for microbial fuel cells with anodic biofilms and anaerobic digestion. Water Sci. Technol. 2008, 57, 965-971. [CrossRef] [PubMed]

36. Maier, R.; Pepper, I. Environmental Microbiology, 3rd ed.; Academic Press: Cambridge, MA, USA; Elsevier: Amsterdam, The Netherlands, 2015.

37. Zhang, X.C.; Halme, A. Modelling of a microbial fuel cell process. Biotechnol. Lett. 1995, 17, 809-814. [CrossRef]

38. Abul, A.; Zhang, J.; Steidl, R.; Reguera, G.; Tan, X. Microbial fuel cells: Control-oriented modeling and experimental validation. Am. Control Conf. 2016, 412-417. [CrossRef]

39. Pinto, R.P.; Srinivasan, B.; Manuel, M.F.; Tartakovsky, B. A two-population bio-electrochemical model of a microbial fuel cell. Bioresour. Technol. 2010, 101, 5256-5265. [CrossRef]

40. Recio-Garrido, D.; Perrier, m.; Tartakovsky, B. Combined bioelectrochemical-electrical model of a microbial fuel cell. Bioprocess Biosyst. Eng. 2016, 39, 267-276. [CrossRef]

41. Zeng, Y.; Choo, Y.F.; Kim, B.H.; Wu, P. Modelling and simulation of two-chamber microbial fuel cell. J. Power Sources 2010, 195, 79-89. [CrossRef]

42. Oliveira, V.B.; Simões, M.; Melo, L.F.; Pinto, A.M.F.R. A 1D mathematical model for a microbial fuel cell. Energy 2013, 61, 463-471. [CrossRef]

43. Esfandyari, M.; Fanaei, M.A.; Gheshlaghi, R.; Mahdavi, M.A. Mathematical modeling of two-chamber batch microbial fuel cell with pure culture of Shewanella. Chem. Eng. Res. Des. 2016, 117, 34-42. [CrossRef]

44. Shankar, R.; Mondal, P.; Chand, S. Modelling and simulation of double chamber microbial fuel cell: Cell voltage, power density and temperature variation with process parameters. Green 2013, 3, 181-194. [CrossRef]

45. Torres, I.; Rittmann, B.E.; Marcus, A.K. Conduction-Based Modeling of the Biofilm Anode of a Microbial Fuel Cell. Biotechnol. Bioeng. 2007, 98,1171-1182.

46. Jayasinghea, N.; Franksb, A.; Nevinb, K.P.; Mahadevan, R. Metabolic Modelling of Spatial Heterogeneity of Biofilms in Microbial Fuel Cells Reveals Substrate Limitations in Electrical Current Generation. Biotechnol. J. 2014, 9, 1350-1361. [CrossRef] [PubMed]

47. Sirinutsomboon, B. Modeling of a membraneless single-chamber microbial fuel cell with molasses as an energy source. Int. J. Energy Environ. Eng. 2014, 5, 1-9. [CrossRef]

48. Picioreanu, C.; Katuri, A.P.; Van Loosdrecht, M.C.M.; Head, I.M.; Scott, K. Modelling microbial fuel cells with suspended cells and added electron transfer mediator. J. Appl. Electrochem. 2010, 40, 151-162. [CrossRef]

49. Picioreanu, C.; Head, I.M.; Katuri, K.P.; Van Loosdrecht, M.C.M.; Scott, K. A computational model for biofilm-based microbial fuel cells. Water Res. 2007, 41, 2921-2940. [CrossRef]

50. Esfandyari, M.; Fanaei, M.A.; Gheshlaghi, R.; Mahdavi, M.A. Dynamic modeling of a continuous two-chamber microbial fuel cell with pure culture of Shewanella. Int. J. Hydrogen Energy 2017, 42, 21198-21202. [CrossRef]

51. Pinto, R. P.; Tartakovsky, B.; Perrier, M.; Srinivasan, B. Optimizing Treatment Performance of Microbial Fuel Cells by Reactor Staging. Ind. Eng. Chem. Res. 2010, 49, 9222-9229. [CrossRef]

52. Naureen, Z.; Ali, Z.; Al, R.; Nasser, M.; Jabri, A.; Khalfan, S.; Housni, A.; Gilani, S.A.; Mabood, F.; Farooq, S.; et al. Generation of Electricity by Electrogenic Bacteria in a Microbial Fuel Cell Powered by Waste Water. Adv. Biosci. Biotechnol. 2016, 7, 329-335. [CrossRef]

53. Patel, R.; Deb, D.; Dey, R.; Balas, V.E. Adaptive Control of Single Population Single Chamber MFC. In Adaptive and Intelligent Control of Microbial Fuel Cells; Intelligent Systems Reference Library; Springer Nature Switzerland AG: Basel, Switzerland, 2020; Volume 161.

54. Patel, R.; Deb, D. Parametrized Control-Oriented Mathematical Model and Adaptive Backstepping Control of a Single Chamber Single Population Microbial Fuel Cell. J. Power Sources 2018, 396, 599-604. [CrossRef]

55. Babanova, S.; Hubenova, Y.; Mitov, M.; Mandjukov, P. Uncertainties of Yeast-Based Biofuel Cell Operational Characteristics. Fuel Cells 2011, 11, 824-837. [CrossRef]

56. Coronado, J.; Tartakovsky, B.; Perrier M. On-line monitoring of microbial fuel cells operated with pulse-width modulated electrical load. J. Process Control 2015, 35, 59-64. [CrossRef]

57. Park, J.; Roane, T.; Ren, Z.; Alaraj, M. Dynamic modeling of a microbial fuel cell considering anodic electron flow and electrical charge storage. Appl. Energy 2017, 193, 507-514. [CrossRef] 
58. Rismani-Yazdi, H.; Carver, S.M.; Christy, A.D.; Tuovinen, O.H. Cathodic limitations in microbial fuel cells: An overview. J. Power Sources 2008, 180, 683-694. [CrossRef]

59. Manohar, A.K.; Mansfeld, F. The internal resistance of a microbial fuel cell and its dependence on cell design and operating conditions. Electrochim. Acta 2009, 54, 1664-1670. [CrossRef]

60. He, Z.; Mansfeld, F. Exploring the use of electrochemical impedance spectroscopy (EIS) in microbial fuel cell studies. Energy Environ. Sci. 2009, 2, 215-219. [CrossRef]

61. Cooper, K.R.; Smith, M. Electrical test methods for online fuel cell ohmic resistance measurement. J. Power Sources 2006, 160, 1088-1095. [CrossRef]

62. Ren, Z.; Yan, H.; Wang, W.; Mench, M.M.; Regan, J.M. Characterization of Microbial Fuel Cells at Microbially and Electrochemically Meaningful Time scales. Environ. Sci. Technol. 2011, 45, 2435-2441. [CrossRef]

63. Mingant, R.; Bernard, J.; Sauvant-Moynot, V. Novel state-of-health diagnostic method for Li-ion battery in service. Applied Energy 2016, 183, 390-398. [CrossRef]

64. Hernández-Flores, G.; Poggi-Varaldo, H.M.; Solorza-Feria, O.; Ponce Noyola, M.T.; Romero-Castañón, T.; Rinderknecht-Seijas, N. Tafel equation based model for the performance of a microbial fuel cell. Int. J. Hydrogen Energy 2015, 40, 17421-17432. [CrossRef]

65. Sindhuja, M.; Kumar, N.S.; Sudha, V.; Harinipriya, S. Equivalent circuit modeling of microbial fuel cells using impedance spectroscopy. J. Energy Storage 2016, 7, 136-146. [CrossRef]

66. Zhihao, L.; Peter, G.; Peng, L.; Haifeng, S.; Guangtuan, H.; Lankun, C.; Lehua, Z. Biological capacitance studies of anodes in microbial fuel cells using electrochemical impedance spectroscopy. Bioprocess Biosyst. Eng. 2015, 38, 1325-1333.

67. Dhiman, H.S.; Deb, D.; Guerrero, J.M. Hybrid Machine Intelligent SVR Variants For Wind Forecasting In addition, Ramp Events. Renew. Sustain. Energy Rev. 2018, 108, 369-379. [CrossRef]

68. Dhiman, H.S.; Deb. D.; Balas. V.E. Supervised Machine Learning in Wind Forecasting and Ramp Event Prediction; Apple Academic Press, Elsevier: Amsterdam, The Netherlands, 2020.

69. Fang, F.; Zang, G.; Sun, M.; Yu, H. Optimizing multi-variables of microbial fuel cell for electricity generation with an integrated modeling and experimental approach. Appl. Energy 2013, 110, 98-103 [CrossRef]

70. Esfandyari, M.; Fanaei, M.; Gheshlaghi, R.; Mahdavi, M. Neural network and neuro-fuzzy modeling to investigate the power density and Columbic efficiency of microbial fuel cell. J. Taiwan Inst. Chem. Eng. 2015, 58, 84-91. [CrossRef]

71. Garg, A.; Vijayaraghavan, V.; Mahapatra, S.; Tai, K.; Wong, C. Performance evaluation of microbial fuel cell by artificial intelligence methods. Expert Syst. Appl. 2014, 41, 1389-1399. [CrossRef]

72. Boghani, H.; Kim, J.; Dinsdale, R.; Guwy, A.; Premier, G. Analysis of the dynamic performance of a microbial fuel cellusing a system identification approach. J. Power Sources 2013, 238, 218-226. [CrossRef]

73. Boghani, H.; Michie, I.I.; Dinsdale, R.; Guwy, A.; Premier, G. Control of microbial fuel cell voltage using a gain scheduling control strategy. J. Power Sources 2016, 322, 106-115. [CrossRef]

74. Patel, R.; Deb, D.; Dey, R.; Balas, E.V. Model Reference Adaptive Control of Microbial Fuel Cells. In Adaptive and Intelligent Control of Microbial Fuel Cells; Intelligent Systems Reference Library; Springer Nature Switzerland AG: Basel, Switzerland, 2020; Volume 161.

75. Yewale, A.; Methekar, R.; Agrawal, S. Dynamic analysis and multiple model control of continuous microbial fuel cell (CMFC). Chem. Eng. Res. Des. 2019, 48, 403-416. [CrossRef]

76. Yan, M.; Fan, L. Constant Voltage Output in Two-Chamber Microbial Fuel Cell Under Fuzzy PID Control. Int. J. Electrochem. Sci. 2013, 8, 3321-3332.

77. Fan, L.; Li, C.; Boshnakov, K. Performance improvement of a microbial fuel cell based on adaptive fuzzy control. Pak J. Pharm. Sci. 2014, 27, 685-690. [PubMed]

78. Fan, L.; Zhang, J.; Shi, X.; Performance Improvement of a Microbial Fuel Cell based on Model Predictive Control. Int. J. Electrochem. Sci. 2015, 10, 737-748.

79. Patel, R.; Deb, D. Nonlinear adaptive control of microbial fuel cell with two species in a single chamber. J. Power Sources 2019, 434, 226739. [CrossRef]

80. Patel, R.; Deb, D.; Dey, R.; Balas, E.V. Robust Control Design of SPSC Microbial Fuel Cell with Norm Bounded Uncertainty. In Adaptive and Intelligent Control of Microbial Fuel Cells; Intelligent Systems Reference Library; Springer Nature Switzerland AG: Basel, Switzerland, 2020; Volume 161. 
81. Patel, R.; Deb, D.; Dey, R.; Balas, V.E. Exact Linearization of Two Chamber Microbial Fuel Cell. In Adaptive and Intelligent Control of Microbial Fuel Cells; Intelligent Systems Reference Library; Springer Nature Switzerland AG: Basel, Switzerland, 2020; Volume 161.

82. Luo, Q.; An, A.; Wang, M. Model Reference Adaptive Control for Microbial Fuel Cell (MFC). In Proceedings of the 2019 4th International Conference on Robotics, Control and Automation-ICRCA, Guangzhou, China, 26-28 July 2019.

83. Zheng, G.; Zhen, H. Long-term performance of a 200 liter modularized microbial fuel cell system treating municipal wastewater: Treatment, energy, and cost. Environ. Sci. Water Res. Technol. 2016, 2, 235-406.

84. Mojtaba, M.; Ewa, Z.; Jacek, M. Achieving energy neutrality in wastewater treatment plants through energy savings and enhancing renewable energy production. Rev. Env. Sci. Biotechnol. 2018, 17, 655-689.

85. Vilajeliu-Pons, A.; Puig, S.; Salcedo-Dávila, I.; Balaguer, M.D.; Colprim, J. Long-term assessment of six-stacked scaled-up MFCs treating swine manure with different electrode materials. Environ. Sci. Water Res. Technol. 2017, 3, 947-959. [CrossRef]

(c) 2020 by the authors. Licensee MDPI, Basel, Switzerland. This article is an open access article distributed under the terms and conditions of the Creative Commons Attribution (CC BY) license (http://creativecommons.org/licenses/by/4.0/). 